\title{
The International Financial Services (IFS) Sector in Vanuatu
}

\section{I Introduction}

Vanuatu or New Hebrides (when it was a British-French Condominium prior to 1980) is a small developing Pacific island country located about 800 kilometres west of Nadi, Fiji Islands and about 2,500 kilometres northeast of Sydney, Australia.

The island nation is made up of a chain of 83 islands and has a population of 205,754. The capital city is Port Vila, which is located on the island of Efate and has a population of about 30,000 . The island has a dualistic economy, with a large subsistence agricultural sector, which is supplemented by the financial and tourism sectors.

Vanuatu has a 52-member parliament, which is based on the British system and is headed by a Prime Minister. The head of state is the President, who is elected by Members of Parliament and the Presidents of Provincial Councils. The legal system is also based on the British law model and the judiciary is headed by the Chief Justice. The Court of Appeal is the highest appellate court, followed by the Supreme Court and the Magistrate Court. In addition, there is a National Council of Chiefs, which advises the government on culture and language and looks after the interests of the chiefs.

Vanuatu's international financial centre started in 1969 when it was still a Condominium on the advice of the British government. By 1970 and early 1971 a full offshore regime was legislated.

\subsection{Origins and developments of the IFS sector in Vanuatu}

An international finance centre (IFC) is a jurisdiction that levies no, or very low, direct corporate and personal income taxes. Such a jurisdiction may also be known as an offshore finance centre (OFC) 'that hosts financial activities that are separated from major regulating units (states) by geography and/or by legislation'”. Most IFCs are based on English common law. Countries and territories that host IFC facilities offer a legal system that provides for the formation of international companies and trusts that can be used in the management of tax neutral portfolios and worldwide assets.

The country's international finance centre has had an important effect on the history of Vanuatu (formerly known as the New Hebrides). From 1970, it greatly boosted the revenues of the pro-independence British administration and reduced the relative 
importance of the French. The IFC brought lawyers, trustees and bankers to Port Vila, particularly from Australia and New Zealand ${ }^{2}$.

The initial legislation upon which the offshore sector was founded are the:

- Banking Act [Cap 63] (repealed and replaced by the Banking Act of 2002)

- Trust Companies Act [Cap 69]

- Prevention of Fraud (Investment) Act [Cap 70]

- Insurance Act [CAP 82]

Later, after independence, the Vanuatu government introduced further legislation to compliment the existing IFS framework. The additional governing laws of the IFC are:

- Companies Act [CAP 191]

- Serious Offences (Confiscation of Proceeds) Act No. 50 of 1989

- Casino Control Act No. 6 of 1993

- Financial Institution Act No. 2 of 1999

- International Companies Act No. 32 of 1992

- Financial Transactions Reporting Act No. 33 of 2000

- International Banking Act No. 4 of 2002

- Proceeds of Crime Act No. 13 of 2002

- Mutual Assistance in Criminal Matters Act No. 14 of 2002

- Betting (Control) Act No.37 of 2003

- Insurance Act of $2005^{3}$

The international finance centre of Vanuatu provides the four most important general products: international business companies (IBCs), or international companies as they are known locally, offshore banks, exempted insurers and offshore trusts. These products are governed by the International Companies Act No. 32 of 1992 (last amended in 2000), the International Banking Act No. 4 of 2002, the Insurance Act of 2005 and the Trust Companies Act of 1971 (last amended in 1988) respectively. Offshore financial products are usually used for the purposes of minimising tax and/or to protect assets.

In 1970 the banks and banking regulation legislation and the company regulation legislation were introduced, and in the same year ANZ opened its first branch in Port Vila. The Trust Company Act was introduced in 1971, and by 1973 other banks including the Bank of New South Wales, National Australia Bank, Barclays, Commonwealth Bank and HSBC were all licensed in the New Hebrides (as Vanuatu then was). Ten trust companies were in operation and the Insurance Act was also introduced ${ }^{4}$. Both population and land prices in Port Vila experienced very rapid growth as Vanuatu attracted business fleeing perceived political instability in IFCs like the Bahamas and Bermuda. 
By 1976, the IFC was truly established. At independence in 1980, the first Prime Minister, Father Walter Lini, and all prominent Vanuatu politicians expressed support for the IFC. The Reserve Bank of Vanuatu (RBV) was created and all stakeholders felt the IFC was 'here to stay'. In 1989, the first anti-money laundering (AML) laws, the Mutual Assistance in Criminal Matters and Serious Offences (Confiscation of Proceeds) Act were introduced.

Then in 1993, Vanuatu introduced its first dedicated international company legislation (International Companies Act 1992) to restore competitiveness with other IFCs in this area. The legislation was based on the IBC law of the British Virgin Islands as well as New Zealand company law. Previously, foreign investors had made use of the provision for exempt status in the normal company legislation. Vanuatu's international company legislation restricts the ability of such companies to conduct business in the country under a ring-fencing provision.

International companies are commonly used to provide secrecy for their owners in a number of ways. To guarantee such privacy, company registries are not open for public inspection $^{5}$. If this secrecy provision is breached, the perpetrator(s) face criminal prosecution and jail. International companies do not have to pay any local taxes and duties and are subject to low reporting requirements. Vanuatu does not have offshore trust legislation, but trusts are commonly used in the IFS sector.

The Vanuatu Financial Services Commission (VFSC) was established in 1993, and in 1994 a promotions committee with the Finance Centre Association was set up to advertise the IFC in Australia, New Caledonia, Hong Kong and Eastern Europe. In 1995, the Banking Act [Cap 63] was amended and supervision of offshore banks was transferred from the Minister of Finance to the VFSC, which set up a Bank Supervision Unit. At this time the fee for an offshore bank licence was increased to $\$ 5,000$.

In December 1999, a group of United States banks decided to suspend electronic banking links with Vanuatu, Nauru and Palau following Congressional testimony alleging links between these centres and money laundering. In January 2000, a joint government/private sector mission from Vanuatu went to Washington and New York to meet with officials. The ban was lifted for the country's domestic licensed banks.

In 2000, there was a joint assessment visit by the Asia-Pacific Group on Money Laundering (APG) and the Offshore Group of Banking Supervisors (OGBS). In addition, in the same year Vanuatu was reviewed by the Financial Action Task Force (FATF) as part of the Non-Cooperative Countries and Territories (NCCT) exercise. The Financial Transactions Report Act was introduced in September 2000 to avoid Vanuatu's being placed on the NCCT list. In May and June 2000, Vanuatu was placed on the lowest tier of the Financial Stability Forum's (FSF) three-tier categorisation of the perceived quality of IFC supervision, and included in the OECD's Tax Havens list with 34 other jurisdictions as part of the Harmful Tax Competition initiative.

The International Monetary Fund (IMF) performed a Module 2 Assessment of Vanuatu's offshore and domestic financial sectors in 2002. The resulting report (published in 
2003) made major recommendations to transfer regulatory responsibilities from the VFSC to the RBV, dilute secrecy provisions, overhaul the offshore legal structure and conduct a cost-benefit analysis of the IFS industry. This report also estimated the gross contribution of the offshore sector to government revenues at US\$1 million. At this time, the VFSC had 13 staff (two in banking supervision) and the RBV had 53 staff, four in (domestic) banking supervision. The OECD 'Unco-operative Tax Havens' list, published in April of 2002, included Vanuatu along with six other jurisdictions.

In response to the IMF report, in 2003 the International Banking Act was introduced, the major innovation being that offshore banks were required to have a permanent office with the bank's records and at least one full-time employee in Port Vila. As a direct result, the number of exempted (offshore) banks dropped from 35 to nine in the subsequent 12 months. Offshore bank supervision was moved from the VFSC to the $\mathrm{RBV}$, and the licence fee was increased to US\$8,000.

Before 2002, offshore banks were accorded more privacy and greater flexibility in operation, as they were not required to have any physical presence (office/staff) in Vanuatu. Also, they were not required to disclose company records to the public, were free from all forms of inspection and did not have to comply with strict capital adequacy requirements. Since 2002, however, offshore banks must maintain an office in Vanuatu, must have a resident manager/full-time employee based in the country and are subject to compliance inspections by the Reserve Bank of Vanuatu ${ }^{6}$. Offshore banks are still forbidden from accepting deposits from the public in Vanuatu, and from soliciting business locally, and in this regard these banks can still be distinguished from local banks.

In May 2003, Vanuatu reversed its earlier decision and agreed to commit to the principles of tax information exchange and transparency required by the OECD, and as a result Vanuatu was removed from the 'Unco-operative Tax Haven' list.

In 2005, a new Insurance Act was passed, and the Australian government made a formal request to enter into negotiations concerning a bilateral Tax Information Exchange Agreement (TIEA) with Vanuatu.

At the time of writing (2006) it was planned that the VFSC would move to immobilise bearer shares according to British Virgin Island model of custodianship, and would register corporate and trust service providers in line with the Isle of Man model. The supervision of insurance companies and trust providers may also be transferred from the VFSC to the RBV. Despite this transfer of responsibility, however, there are no plans to reduce staffing at the VFSC. There are plans to legislate for the provision of new products, such as protected cell companies, based on the Guernsey model, unit trusts and mutual funds. For this, the State Law Office will need expert advice from draftpersons and funding to be able to secure such services. Also, if these laws were passed then regulators would need to recruit at least two more staff per office to carry out the additional supervisory work ${ }^{7}$.

The private sector industry, i.e. the banks, insurance companies, accountants, trust companies, lawyers and other service providers, has an organisation called the Vanuatu 
List of legislation under which the IFC operates and their amendments

\begin{tabular}{lll}
\hline No. Act & Amendments \\
\hline 1. Banking Act & Banking Regulation (Amendment) Act No.4 of 1989, \\
[Cap 63] & commenced on 29 December 1989 \\
(repealed in 2002) & Banking (Amendment) Act No.7 of 1995, commenced on 28 \\
& August 1995 \\
& Banking (Repeal) Act No.18 of 2002, commenced on 01 \\
& January 2003 \\
& Amended by the QR 6 of 1971 \\
2. Trust Companies Act & Amended by the QR 3 of 1973 \\
[Cap 69] & Amended by the QR 16 of 1973 \\
& Amended by the QR 5 of 1978 \\
& Amended by the QR 6 of 1978 \\
& Amended by Act No. 18 of 1984 \\
& Amended by Act No.10 of 1988 \\
& Amended by the QR 9 of 1971 \\
3. Prevention of Fraud & Amended by the QR 3 of 1978 \\
(Investment) Act & Amended by Act No.10 of 1988 \\
[Cap 70] & Amended by the QR 18 of 1973 \\
4. & Amsurance Act & Amended by the QR 11 of 1974 \\
[Cap 82] & Amended by the QR 2 of 1975 \\
& Amended by Act No. 10 of 1978 \\
&
\end{tabular}

5. Companies Act

No. 12 of 1986

6. Serious Offences Repealed in February 2003

(Confiscation of Proceeds)

Act No.50 of 1989

7. Betting Control Act 1 of 1993

Repealed and replaced by the Betting (Control) (Repeal) Act

8. Casino Control Act No.6 of 1993 No. 37 of 2003

Casino Control (Amendment) Act No.7 of 1996

Casino Control (Amendment) Act No.25 of 1998

Casino Control (Amendment) Act No.4 of 2001

Casino Control (Amendment) Act No.6 of 2005

9. Financial Institution

Financial Institution (Amendment) Act No.20 of 2002 Act No.2 of 1999

10. International Companies Act No.32 of 1992

International Companies (Amendment) Act No.26 of 1993

International Companies (Amendment) Act No.9 of 1994

International Companies (E-Commerce) (Amendment) Act No.26 of 2000

11. Financial Transactions Reporting Act No.33

Financial Transactions Reporting (Amendment) Act No.20 of 2002

of 2000

Financial Transactions Reporting (Terrorism) (Amendment) Act No.2 of 2002

12. International Banking Act No. 4 of 2002

13. Proceeds of Crime Act No. 13 of 2002

14. Mutual Assistance in Criminal Matters Act No. 14 of 2002

15. Insurance Act of 2005 
Financial Centre Association (VFCA). The VFCA is governed by a constitution and has membership requirements, sanctions and a code of conduct for members. Members of the VFCA meet once a month and liaise between the private sector and government.

\subsection{The importance of IFS to the Vanuatu economy}

Vanuatu has a domestic financial sector and an international financial sector. The domestic sector consists of banks, insurance, accountants, lawyers and other financial institutions. ANZ, Westpac and the National Bank of Vanuatu (which is government owned) operate within Vanuatu as local banks and operate in the international sector as well. European Bank is registered as a domestic bank, but mainly operates in the international sector. There are currently seven offshore banks registered (with four applications pending for registration) and five local insurance companies operating in Vanuatu. There are eight accounting firms, of which five correspond with international firms.

The Vanuatu National Provident Fund is a statutory fund established by the government in 1987 to function as a compulsory superannuation scheme. It controls the retirement savings ( 8 per cent of wages and salary) of all employees. Vanuatu also has modern telecommunication and Internet services provided by Telecom Vanuatu Limited, which is important for the international financial services (IFS) sector for trading reasons.

The international sector comprises offshore banks, offshore insurance companies, shipping, trust and company service providers. Currently the most important product is international companies, the number of which is stable at around 4,500. These have had the advantage of enhanced privacy and confidentiality guaranteed under the International Companies Act of 1992; however, since 2000 this privilege has been diluted to some extent by the new anti-money laundering/countering financing of terrorism (AML/CFT) regulatory requirements.

\section{Contribution to the economy/GDP}

It is difficult to assess accurately the financial contribution of the offshore centre to the economy of Vanuatu. This is mainly because of the integration between the domestic and offshore sector. However, through government statistics and information from the private and public sector, some degree of assessment is possible.

The main difficulty relating to the private sector is in identifying the proportion of revenue generated by the various accounting and law firms undertaking offshore activities (in terms of their acting as company officers and administering international companies, for example), but which also maintain their own professional practices. The public sector regulatory bodies also have dual responsibilities in regulating both the offshore and domestic sectors ${ }^{8}$.

According to an earlier cost-benefit analysis carried out in 2004, the best way to define the two sectors is through determining the residential status of the clients or customers 
to separate residents from non-residents. If this classification is used, then shipping and Internet gambling would be part of the offshore industry. However, even this approach involves problems, as some 'offshore' clients invest directly in the country and/or become residents of the country over time ${ }^{9}$.

The income tax-free regime in Vanuatu that applies to both resident and non-resident owned operations also creates a problem, as it often makes it difficult to distinguish between what is offshore and what is domestic activity. Shipping, the E-commerce industry and Internet gambling are administered by the government separately to other offshore operations. Even though they are not formally part of the private offshore sector, however, these activities involve many of the same operators, and in the case of shipping, directly involve the use of international companies registered through the $\mathrm{IFC}^{10}$.

Identifying the gross revenue of the offshore sector assists in determining the contribution of the IFS industry to the general economy. One of the main sources of government revenue derived from the offshore sector is the annual fees charged by the VFSC. There is a set annual fee for each type of company registration, which varies by the authorised capital for local companies. According to the Commissioner of the VFSC, the fees charged by the Vanuatu registry are highly competitive compared to other IFCs.

In general, the Government of Vanuatu derives its revenues from various registration and license fees, stamp and customs duties and consumer taxes such as the VAT (12.5 per cent). This is mainly collected from the domestic sector rather than IFS.

Local industry representatives claim the offshore sector contributes upwards of 12 per cent of GDP 11 . Most recent IMF figures put the direct contribution of the IFC (excluding the shipping registry) at 3 per cent of GDP and 1.5-2 per cent of government revenue $^{12}$. However, a recent cost-benefit assessment funded by the Pacific Islands Forum Secretariat at the request of the government of Vanuatu estimated that in mid2004 the entire 'offshore industry' represented 9.7 per cent of GDP and 5.1 per cent of government revenues. The Reserve Bank of Vanuatu (RBV), meanwhile, estimates that the figures are currently 9 per cent and 5.5 per cent respectively ${ }^{13}$.

Much of this discrepancy between the IMF and other figures results from disagreement about how to measure the indirect 'spin-off' benefits of the IFS industry for the general economy. The Ministry of Finance has previously estimated the multiplier effect ${ }^{14}$ as being 2.5, which (when including the shipping registry) would largely resolve the conflicting figures on the contribution of the IFS sector as a proportion of GDP.

\section{Offshore (exempt) banks}

Offshore banks operate in a closed environment, and generally do not form part of the local industry in Vanuatu. As the name suggests, these banks are allowed to operate overseas as exempt companies through the IFC. The offshore banking sector had a healthy growth rate until 1993, at which time its numbers peaked at 120 licensed banks. After 1993, offshore banks experienced a decline to 92 in 1995. This pattern of 
decline began to take place even before the recent regulatory changes. By 2000, the number of banks had reduced steeply to 59 , with only seven remaining by $2005^{15}$. The offshore banking sector was previously dominated by shell operations. With the enactment of the International Banking Act of 2002, which required a physical presence through an office and staff to be located in Vanuatu, a majority of the remaining licensees withdrew from the IFC.

At the time of writing (2006), only seven offshore banking licenses and one general banking license were issued to offshore banking operations in Vanuatu ${ }^{16}$. Only three of the offshore banks have significant physical presence in Vanuatu, employing between five and seven staff each. However, the remaining banks are in the process of establishing business operations as required by the new International Banking Act of 2002. Overall, approximately 20 people are employed locally by the offshore banks ${ }^{17}$.

The operating offshore banks are not associated with any international banking or financial service institutions. They are held by private interests and generally operate in niche markets and products. Offshore bank assets amounted to US $\$ 202.3$ million at the end of 2005, a significant drop since March 2003 when such assets were recorded at US $\$ 1,442$ million. The offshore banking sector generates around 14 million vatu $(\mathrm{Vt})^{18}$ per year (US\$127,680 at the inter-bank rate), which is about 0.4 per cent of the overall GDP ${ }^{19}$.

The RBV believes that, following the International Banking Act of 2002, there are now greater prospects for the development for the offshore banking industry. An indication of the potential growth in this area is that there are currently four pending applications for new offshore bank licenses ${ }^{20}$.

\section{Trusts}

At the time of writing, 11 trust company licenses had been issued, of which three operate independently in the offshore sector and the rest operate in conjunction with legal and accounting firms ${ }^{21}$. Vanuatu has no trust legislation such as that in the Cook Islands and other IFCs.

\section{International companies}

Offshore company registration is the main offshore activity in Vanuatu. The bulk of clients are from Australia, New Zealand and Asia.

These international companies are awarded enhanced privacy rights and confidentiality. They are not required to file annual accounts or reports similar to Australia, New Zealand and the USA and their records are not open to the public unless special permission is acquired from the company director ${ }^{22}$. The number of offshore companies peaked during the 1990s, but has remained stable or slightly in decline since 2000. The 2004 cost-benefit analysis attributes this to 'increased competition through developed technology and aggressive pricing from other jurisdictions such as the British Virgin Islands and Samoa' ${ }^{23}$. 
Vanuatu has a tiny share of the IBC market by international standards, with 4,664 international companies currently registered through its $\mathrm{IFC}^{24}$. This is compared to other IFCs such as Samoa, which has over 20,000 such companies, and the British Virgin Islands with over 400,00025.

\section{Offshore insurance}

The number of offshore insurance firms has significantly increased in recent years, with the number of offshore insurers increasing from 15 at the end of 2002 to 26 at the

Table 10.1 International company registrations ${ }^{26}$

\begin{tabular}{lccccccccccc}
\hline $\begin{array}{l}\text { Year of } \\
\text { registration }\end{array}$ & 1980 & 1986 & 1992 & 1995 & 1999 & 2000 & 2001 & 2002 & 2003 & 2004 & 2005 \\
\hline $\begin{array}{l}\text { Cumulative } \\
\text { total }\end{array}$ & 505 & 666 & 1,018 & 1,419 & 2,911 & 4,015 & 4,330 & 4,690 & 4,462 & 4,561 & 4,786 \\
Net increase & - & 150 & 184 & 401 & 1492 & 1104 & 315 & 360 & $(228)$ & 99 & 225 \\
\hline
\end{tabular}

Table 10.2 Offshore client entities by registration/establishment as at January $2006^{27}$

\begin{tabular}{lccccccc}
\hline Entity & $\begin{array}{c}\text { International } \\
\text { companies }\end{array}$ & $\begin{array}{c}\text { Exempt } \\
\text { companies }\end{array}$ & $\begin{array}{c}\text { Offshore } \\
\text { insurers }\end{array}$ & $\begin{array}{c}\text { Offshore } \\
\text { banks }\end{array}$ & $\begin{array}{c}\text { Trust } \\
\text { companies }\end{array}$ & Ships & Total \\
\hline Number registered & 4,664 & 122 & 23 & 7 & 11 & 600 & 5,427 \\
\% of total & 85.94 & 2.25 & 0.42 & 0.13 & 0.20 & 11.06 & \\
\hline
\end{tabular}

Table 10.3 Total companies registrations ${ }^{28}$

\begin{tabular}{lcccccccc}
\hline $\begin{array}{l}\text { Type of } \\
\text { company }\end{array}$ & $\begin{array}{c}\text { Local } \\
\text { company }\end{array}$ & $\begin{array}{c}\text { Overseas } \\
\text { company }\end{array}$ & $\begin{array}{c}\text { Exempt } \\
\text { company }\end{array}$ & $\begin{array}{c}\text { International } \\
\text { company }\end{array}$ & $\begin{array}{c}\text { Charitable } \\
\text { organisations }\end{array}$ & $\begin{array}{c}\text { Trade } \\
\text { unions }\end{array}$ & $\begin{array}{c}\text { Credit } \\
\text { unions }\end{array}$ & $\begin{array}{c}\text { Business } \\
\text { names }\end{array}$ \\
\hline Total & 1,364 & 27 & 122 & 4,664 & 65 & 3 & 1 & 830 \\
\hline
\end{tabular}

Table 10.4 Specialised licenses ${ }^{29}$

\begin{tabular}{|c|c|c|c|}
\hline $\begin{array}{c}\text { Type of company } \\
\text { Total }\end{array}$ & $\begin{array}{c}\text { Trust license } \\
12\end{array}$ & $\begin{array}{c}\text { Insurance license } \\
40\end{array}$ & $\begin{array}{c}\text { Security dealers } \\
4\end{array}$ \\
\hline & & (Local - 5 & \\
\hline & & External - 3 & \\
\hline & & Exempt -23 & \\
\hline & & Brokers - 4 & \\
\hline & & Agents - 5) & \\
\hline
\end{tabular}


end of $2005^{30}$. This is in comparison to the five domestic insurance companies operating within Vanuatu.

Offshore insurers have only a minimal presence in Vanuatu compared with the offshore banks, and are almost exclusively managed by the local trust companies. They provide for 'mainly captive insurance business primarily sourced out of North America, with some finance-based insurance products marketed into Australia' ${ }^{\prime 3}$. The offshore insurance sector is still small by most standards and is in a development stage. A new Insurance Act was passed in late 2005, but its impact on offshore insurance is yet to be seen. The private sector is, however, concerned that the stricter requirements imposed by new Act will mean that offshore and captive insurance companies will exit Vanuatu.

\section{Shipping}

In the late 1980s, Vanuatu became popular as an international shipping registry; since that time the country has seen a steady growth, with about 600 international ships now registered ${ }^{32}$.

Even though the shipping industry is not directly dependent on the rest of the offshore sector, it relies largely on the generally tax-free operating environment in Vanuatu. It contributes significantly to offshore revenues by making up 10 per cent of the total revenue generated by the offshore sector and about 28 per cent of the overall offshore contribution to government revenues ${ }^{33}$.

The administration of the shipping registry has been under private contract since 1981, when the international shipping registry commenced, producing gross returns of approximately Vt100 million (US\$912,000) per annum for that period. The shipping registry is operationally administered in New York and there is a central registry (kept at Vanuatu Maritime Authority [VMA]) in Port Vila, Vanuatu ${ }^{34}$.

\section{Securities/managed funds/E-commerce}

The E-commerce sector offers services such as Internet gaming, Internet pharmaceutical operations and credit card processing. It is relatively small and still developing as an industry in Vanuatu. The E-commerce sector works through the offshore industry, yet it relies just as much on the domestic environment. The services provided and infrastructure of Vanuatu, zero or low domestic tax rates and low general operating costs, are important to the future growth of these offshore industries ${ }^{35}$.

Moreover, the local banks also earn some revenue for the government through the funds invested by offshore entities. At the end of the financial year in 2005, one of the country's domestic banks held Vt32,522 million (US\$298,500,00 as at 31 March 2005) out of which approximately 80 per cent was held in offshore accounts in foreign deposits. The offshore sector overall had Vt415.7 million (US\$3,904,000 as at 31 March 2005) in net foreign exchange earnings at the end of the first quarter in March $2005^{36}$. 
Table 10.5 Registration and annual fees charged by the VFSC ${ }^{37}$

\begin{tabular}{|c|c|c|c|c|c|}
\hline \multicolumn{2}{|l|}{ Company type } & \multicolumn{4}{|c|}{ Local companies } \\
\hline $\begin{array}{ll}\text { Authorised } & \\
\text { capital } & 35 \text { million } \\
\text { (in vatu) } & (\mathrm{m}) \text { or less }\end{array}$ & $>35 m<50 n$ & $m>50 m<100 n$ & $\mathrm{~m}>100 \mathrm{~m}<200 \mathrm{n}$ & $m>200 m<300 m$ & $>300 \mathrm{~m}$ \\
\hline \multicolumn{6}{|l|}{$\begin{array}{l}\text { Registration } \\
\text { fee }\left(V_{t}\right) \\
\end{array}$} \\
\hline $\begin{array}{l}\text { Annual } \\
\text { fee }(\mathrm{Vt})\end{array}$ & 50,000 & 100,000 & 150,000 & 200,000 & 250,000 \\
\hline \multicolumn{2}{|l|}{ Company type } & \multicolumn{4}{|c|}{ Exempt companies } \\
\hline $\begin{array}{l}\text { Authorised capital } \\
\text { (in vatu) }\end{array}$ & $<50$ million & $>50 m<100 m$ & $>100 m<200 m$ & $>200 m<300 m$ & $>300 \mathrm{~m}$ \\
\hline Registration fee $(\mathrm{Vt})$ & 50,000 & 75,000 & 100,000 & 200,000 & 250,000 \\
\hline Annual fee $(\mathrm{Vt})$ & 50,000 & 75,000 & 100,000 & 200,000 & 250,000 \\
\hline \multicolumn{6}{|c|}{ Company type Overseas companies } \\
\hline \multicolumn{6}{|c|}{$\begin{array}{ll}\text { Authorised capital (in vatu) } & \mathrm{n} / \mathrm{a}\end{array}$} \\
\hline \multicolumn{2}{|c|}{ Registration fee $(\mathrm{Vt})$} & 30,000 & & & \\
\hline \multicolumn{2}{|l|}{ Annual fee $(\mathrm{Vt})$} & 30,000 & & & \\
\hline \multicolumn{2}{|l|}{ Company type } & International com & npanies & & \\
\hline \multicolumn{2}{|c|}{ Authorised capital (in vatu) } & $\mathrm{n} / \mathrm{a}$ & & & \\
\hline \multicolumn{2}{|l|}{ Registration fee (US\$) } & 150 & & & \\
\hline \multicolumn{2}{|l|}{ Annual fee (US\$) } & 300 & & & \\
\hline
\end{tabular}

\section{Employment}

The integrated working environment of the domestic and offshore sector makes it difficult to calculate the number of employees working exclusively in the offshore sector. Although the RBV provides employment figures for the financial sector as a whole (600 in March 2005, 531 ni-Vanuatu and 69 expatriates), these do not distinguish between those involved in IFS and those employed in the domestic financial sector. It is probable that over half of this 600 employee figure represents the domestic sector, particularly domestic banking.

The commercial banks employ about 300 staff and offshore banks employ 27 . There are a total of 115 employees working in accounting firms, out of which 26 could be said to be doing IFC work. Insurance and trust companies employ 153 staff, out of which 
53 work in the area of the IFC. Out of the legal firms, five persons work within the $\mathrm{IFC}^{38}$.

\section{Notes}

1. Hampton, M. (1996), p.4.

2. Van Fossen, Anthony B. (2002), pp.38-62 .

3. Note that this Act had yet to be gazetted at the time of writing.

4. G. Rawlings (2004), pp.325-341.

5. See International Companies Act 1992 s 65, which provides that only members of the company or authorised persons can inspect the company records.

6. International Banking Act No.4 of 2002 s14 and s20.

7. Estimate provided by the Commissioner of the VFSC.

8. Weenink, B.G. (2004).

9. Ibid.

10. Ibid.

11. Lindsey Barrett, BDO Accountants.

12. IMF (2005), p.24.

13. Information provided by the research and statistics officer, Mark Mera, at RBV on 20 February 2006.

14. The multiplier effect: that is, the value of the indirect economic benefits from the IFS industry. If the IMF estimates the figure at 4 per cent and the government says more like 10 per cent, then it could be that the IMF was counting only the direct benefits, while the government was adding on the indirect benefits as well.

15. Data provided by the Vanuatu Financial Services Commission (VFSC) and the RBV.

16. Data provided by the RBV.

17. Estimate provided by the deputy governor of RBV, Mr. Peter Tari, during an interview on 6 December 2005.

18. In general, unless specified otherwise currency values for Vanuatu are taken from 1 February 2006.

19. Information provided by the research and statistics officer, Mark Mera, at the RBV on 20 February 2006.

20. Information provided by the banking supervision officer, Nelson Shem, at the RBV on 10 February 2006.

21. Data provided by the VFSC.

22. See International Companies Act 1992 s65.

23. Weenink, B.G. (2004), p9.

24. Statistics at 30 September 2005, as provided by the Vanuatu Financial Services Commission (VFSC).

25. Offshore Investment Company Formation Survey March 2006. Available at http:// www.offshoreinvestment.com [accessed 15 February 2008] 
26. Statistics at 30 September 2005, as provided by the Vanuatu Financial Services Commission (VFSC).

27. Ibid.

28. Ibid.

29. Ibid.

30. Statistics at 31 December 2005, as provided by the Vanuatu Financial Services Commission (VFSC).

31. Weenink, B.G. (2004), p11.

32. Statistics at end of December 2005, as provided by the Vanuatu Maritime Authority (VMA).

33. Weenink, B.G. (2004).

34. Information provided by Mr. Tom Bayer, 7 March 2006.

35. Weenink, B.G. (2004).

36. Reserve Bank of Vanuatu Quarterly Review, March 2005.

37. Statistics at 20 February 2006, as provided by the Vanuatu Financial Services Commission (VFSC).

38. Information provided by research and statistics officer, Mark Mera, at the RBV on 20 February 2006. 